these reforms do for the Soviet Union? That may be a tough question for Soviet economists to answer.

The 1975 price changes in CMEA suggest that the Soviet Union does not wish to continue to subsidize its CMEA partners. Higher prices for Soviet oil may mean more or better CMEA industrial goods delivered to the Soviet Union, more investment in Soviet projects, and/or possibly more political allegiance. There is; however, another possibility. Acceptance by CMEA of annual price changes based on world markets, coupled with reduced levels of bilateral deliveries, may turn out-in the long run-to be an important step toward decentralization in CMEA. Even steps toward convertibility and internal, market-simulating prices are possible. This is an argument one may hear from some East European economists. However, if this occurs, it will probably result from a Soviet decision to disengage economically from Eastern Europe rather than from an educational process in which the more professional Hungarians and Poles have enlightened their colleagues to the east of the superiority of the market process.

Edward Hewett's book is primarily for the specialist. But, because events have moved rapidly since its publication, what the specialist needs is a second edition of this excellent analysis, one that takes into account these recent developments.

JoHN P. HARDT

Congressional Research Service, Library of Congress

\title{
BILATERALISM AND STRUCTURAL BILATERALISM IN INTRA-CMEA TRADE. By Jozef M. P. van Brabant. Rotterdam: Rotterdam University Press, 1973. xiii, 290 pp. 69.50 Dfl.
}

Structural bilateralism is defined as bilateralism within commodity groups. The extent of structural bilateralism within CMEA trade is determined by a commoditycountry reciprocity index extending the country reciprocity index put forward by Frederic Pryor. Brabant's indexes show a wide variation among the CMEA countries within four commodity groups, the highest value being reached in the industrial producers goods group in the early years, and declining by 1965 . There is a somewhat lower but more stable pattern in consumer durables. The behavior of these goods-"hard goods"-is contrasted with that of the "soft goods"-raw materials and foods-in the CMEA, as well as with trade patterns in Western Europe, in both of which reciprocity is lower.

Having established that structural bilateralism is higher in CMEA, Brabant tries to analyze the welfare costs. This is no easy task. It requires, first, an estimate of unconstrained welfare maximizing trade behavior, and, next, some way to measure the cost of departures from this norm. Brabant is more successful in the first respect, determining normative trade relations on the basis of trade-generating coefficients estimated for Western European customs union areas and applying these to the CMEA. Without more information, the most one can say is that when actuals depart from the normatives, there is some welfare loss.

Many of the author's statistical calculations will command wide interest since he explores the extent of bilateralism further than has been done before. The book will probably be a wearying experience for most readers, however, because of its turgid expository style, the high incidence of typographical errors, the imprecision 
of terminology and expression, and the author's exasperating recourse to abbreviations. The reader will frequently waste time trying to make connections between terms, results, and conclusions in different parts of the book, or even deciding what is and what is not a typographical error. Examples include the statement of the error term on page 93, which is at variance with the expression in the equation; the entry "Bleu" in several tables, later "BLEU," which in either case the reader must work out for himself; the definitions relating to expression 2.2 (p. 176), or statements such as the following: "Since trade with the ASC's and the DC's occupies a small share of the CPE's' trade, the trend in the distribution of the CPE's' trade between CMEA and AC's is of special importance for later reference" (p. 187). Apart from the standard abbreviations, most of the others do not occur frequently enough to warrant this treatment and only hinder the reader's progress. None of this is made easier by the absence of an index.

Alan Abouchar University of Toronto

BALTIC HISTORY. Edited by Arvids Ziedonis, Jr., William L. Winter and Mardi Valgemäe. Publications of the Association for the Advancement of Baltic Studies, 5. Columbus, Ohio: Association for the Advancement of Baltic Studies, Ohio State University, 1974. x, 341 pp. Paper.

OBERST VÄCIETIS UND DIE LETTISCHEN SCHUTZEN IM WELTKRIEG UND IN DER OKTOBERREVOLUTION. By Uldis Gērmanis. Stockholm Studies in History, vol. 20. Stockholm: Almqvist and Wiksell, 1974. 336 pp. Paper.

SEARCH FOR SECURITY: A STUDY IN BALTIC DIPLOMACY, 19201934. By Hugh I. Rodgers. Hamden, Conn.: Archon Books, The Shoe String Press, 1975. xii, 181 pp. $\$ 12.00$.

PASAKYTA PARASYTA: KALBOS IR PAREISKIMAI II: 1935-1940. By Antanas Smetona. Edited by Leonas Sabaliunas in collaboration with Vincas Rastenis. Boston: Lithuanian Encyclopedia Press, 1974. 350 pp.

The study of the various nationalities of the Soviet Union has commanded increasing attention from American scholars in recent years, and supportive organizations have proliferated. One such group is the Association for the Advancement of Baltic Studies (AABS), which has already held four biennial conferences and is publishing its own Journal of Baltic Studies. Not only has it brought together Latvian, Estonian, and Lithuanian scholars, it has also drawn in American and German scholars as well as Scandinavians and other East Europeans.

The proceedings of the first two conferences of the AABS were each summarized in single volumes. The third conference, held at the University of Toronto in May 1972, led to the publication of several volumes. Baltic History includes twenty-eight historical papers, loosely organized around the topics of the medieval Baltic states, the eighteenth century, the period between the two world wars, and Baltic foreign relations during World War II.

The papers range in length from six to twenty pages, and nine of them are written in German. In such a varied collection one is sure to find things to disagree with; in some contributions, for example, one might object to nationalist biases. 